\title{
THE KALEIDOSCOPE OF POSSIBILITIES FACING LITHUANIAN STATEHOOD IN 1944
}

\author{
Česlovas Laurinavičius
}

ABSTRACT This study investigates viable alternatives to the situation that developed in Lithuania in 1944, i.e. alternatives to the variant of Soviet Lithuania encompassing Vilnius and Klaipeda.

The conclusion is drawn that Lithuania's sovereignty and territorial determination would have been dependent on the degree of Poland's sovereignty and on a more rigid attitude from Roosevelt and Churchill towards Stalin.

Introduction Raising the issue of the possibilities for Lithuanian statehood of (and that of the other Baltic States) in 1944 during this conference means running the risk of being accused of empty rhetoric. Really, how can one talk about any sovereignty of the Baltic States after the Tehran Conference ${ }^{1}$ when it became quite clear that the Red Army was given the green light to push westwards, and Moscow did not show any sign of revising the destiny of the Baltic States ${ }^{2}$

${ }^{1}$ The main decisions of the Tehran Conference, which determined the changes of the power balance in East-Central Europe, were the opening of a second front in the West (and not in the Balkans) and the agreement in principle of pushing Poland's borders westward ignoring the Polish government. Such decisions meant the geopolitical elimination of Poland as a rival power to the Soviet Union in EastCentral Europe and in the Eastern Baltic. Cf. Sovetskii Soiuz na mezhdunarodnykh konferentsiiakh perioda Velikoi otechestvennoi voiny, 1941-1945 gg.: Sbornik dokumentov. T. 2. Tegeranskaia konferentsia. (Moscow, 1984); H. Kissinger, Diplomacy (New York, 1994), pp. 410-412. Besides, according to Polish representatives, the area to the east of the line Lübeck-Trieste was recognized as operationally totally subordinate to the Red Army. (L. Mitkiewicz, 'Powstanie Warszawskie', Zeszyty Historyczne, 1(1962), pp. 95-156.

2 The diaries of the Lithuanian Communist Romas Šarmaitis, who spent the period between 1941 and 1944 in Moscow, reflect the opinions on the question of the Baltic States. The entry for 21 July 1942 reads: 'Today a solemn commemoration of the introduction of Soviet power... The Hall of Columns, Moscow... The broadcast is also directed to the USA, although our embassies are not yet abolished there. Could the States be referred to as allies? ...The Soviet Union does not disown the Baltic States and is engaged in a campaign among its allies. Hitler can really be lucky that this disagreement still exists among his enemies'. Exactly a year later he 
and there were indications that the West was resigned to the disappearance of the Baltic States from the political map 3 .

Nevertheless, the year 1944 was a time full of dramatic and controversial events, and to eliminate that period from the agenda of a conference devoted to the issue of the Baltic States during the Second World War would mean belittling the importance of the conference itself. On the other hand, some recent Russian data on the Soviet territorial policy in World War Two stimulate not only a revision of the long-known facts but also a patterning of the possibilities and alternatives of $1944 .^{4}$

The search for alternatives should not be understood as a wish to deny the facts. It could be only an attempt to examine the contemporary tendencies that remained in embryo and did not materialize in 1944, but which nevertheless did not lack prospects as would be attested by future events. Those tendencies made Lithuania's sovereignty a reality, albeit only after half a century.

Thus, in terms of strategic possibilities, early in 1944 when the Red Army had still to occupy the Baltic, it was not yet clear what would happen in Germany ${ }^{5}$ and what would happen in Poland and in the Baltic States ${ }^{6}$ when the Russians approached the pre-war

wrote: 'The commemoration of Soviet power was attended Andreev, Vyshinskii, and Shcherbakov. The Allies were given to understand that the Baltic States would be Soviet. It is interesting that initially no major festivities were planned, but later on reverse instructions were received.' Lietuvos ypatingasis archyvas, Vilnius (henceforth LYA), f. 17635, ap. 1, b. 15, fos. 40, 92.

${ }^{3}$ This metamorphosis of the Western view in relation to the Baltic States can be symbolically illustrated by the points of view of the US Undersecretary of State Sumner Welles. On 23 July 1940 he made his famous statement about the nonrecognition of the annexation of the Baltic States; meanwhile in 1944 he published his memoirs, in which the Baltic nations were presented as historically and culturally belonging to Russia (S. Welles, The Time for Decisions (New York, 1944).

${ }^{4}$ See, O.A. Rzheshevskii, 'K istorii anglo-sovetskogo dogovora 1942 g.', Vtoraia mirovaia voina. Aktualnye problemy (Moscow, 1995), pp. 133-150.

${ }^{5}$ A serious pretext for deliberations on an alternative course in the Second World War could be a case of a potentially successful assassination attempt on Hitler's life on 20 July 1944.

${ }^{6}$ Looking at the modern epoch from wider angles it could be argued that the further development of the region could have been significantly affected by a political agreement between Lithuania and Poland. For example, if the LithuanianPolish conflict had been resolved in around 1921 - at that time the chances for such a solution were quite real - in that situation the influence of Soviet Russia (and Germany) would have been reduced in this area and subsequently the Baltic region would have developed differently. (Č. Laurinavičius, 'The Baltic States between East and West: 1918-1940', Lithuanian Foreign Policy Review, no. 1, 1998, pp. 87-96; 
USSR borders. Eventually it was known that the Western Allies officially continued to adhere to the provisions of the Atlantic Charter and did not recognize territorial changes made as a result of aggression; ${ }^{7}$ at that time few could envisage what that attitude would hold in store for the Baltic nations in the immediate future. Besides, the Soviet dictator Joseph Stalin, planning his activities for the year 1944, must also have considered those approaches to a certain extent. And there is reason to believe that more than one scenario was prepared for the probable course of events.

The published documents and the series of events of the period between 1918 and 1920 when the Red Army was also moving westwards (though not as successfully and victoriously as in 1944) show that at the time the Kremlin had prepared a number of strategies relating to Lithuania: the most straightforward Sovietization of Lithuania as 'the Northwest Province'; a Sovietized ethnographic Lithuania with Vilnius; a modified Grand Duchy of Lithuania, the socalled LitBel; a nationalist bourgeois Lithuania with Vilnius as a protectorate of Soviet Russia; and lastly a formally independent or neutralized nationalist bourgeois Lithuanian state without Vilnius. ${ }^{8}$ Regrettably, at the present time our knowledge of the Soviet Russia's policy in relation to the Baltic States in Lenin's day is more wideranging than of Stalin's respective policy. Nevertheless, drawing on the known facts and analogies it is possible to project or reconstruct a certain, no doubt, relative cataloguing of Lithuanian statehood eventualities in 1944.

idem, '20th Century Poles and Lithuanians: in Search of Security', The Polish Foreign Affairs Digest, no. 1, 2001, pp. 153-164). Although the chances for such an agreement were minimal during the Second World War, nevertheless the talks proceeded even in 1944. (W. Borodzewicz, 'Rozmowy polsko-litewskie w Wilnie 1942-1944', Przeglad Historyczny, 80/2 (1989); K. Tarka, Konfrontacja czy wspólpraca? Litwa w polityce Rzq̨du Polskiego na uchodźtwie 1939-1945 (Opole, 1998)).

7 'Atlanto chartija', Visuotine lietuviu enciklopedija, vol. 2, (Vilnius, 2002), p. 136; 'Joint Declaration by the President and Prime Minister, August 12, 1941', W. Churchill, Memoirs of the Second World War (Boston, 1959), pp. 491-492.

${ }^{8}$ Č. Laurinavičius, 'Tarybinio valstybingumo steigimas Lietuvoje', id., Politika ir diplomatija (Kaunas, 1997), pp. 42-65; J.D. White, 'The Revolution in Lithuania 1918-1919', Soviet Studies 23, (1971), pp. 186-200; A. Deruga, 'Leninowska polityka zagraniczna a geneza Litewsko-Białoruskiej Republiki Radzieckiej', $Z$ dziejów stosuńków polsko-radzieckich, vol. 7, 1970, p. 162; W. Naidus, 'Polacy we władzach Litewsko-Bialoruskiej Republiki Radzieckiej', Kwartalnik Historyczny, 74:3(1967), W. Gostyńska, 'Tajne rokowania Polsko-Radzieckie w Mikasewiczach', $Z$ pola Walki, 1967:4. 
Before passing over to a proper analysis of 1944 one more methodological detail must be dealt with. The contingency of statehood, in other words, should mean the probability of functioning as a political subject within the international arena. Of course, one cannot think that it is feasible to model a situation in which Lithuania could be imagined as a power capable of opposing adequate force against a force in the great powers' contest in which Lithuania actually existed. On balance, according to a geopolitical theory, the power of the states can be not only relative but also structural. ${ }^{9}$ And it is characterized not only by its material resources (the number of divisions, economic potential, etc.) but also, first and foremost, by its capability to use the relationship of interests of the great powers for its own sake. The implementation of this capability is conditioned by many factors, the most important of which is an adequate and perfectly coherent perception and evaluation of the situation. A clarification of these issues in the context of contemporary Lithuania is the aim of this article.

Eventuality of Lithuania without Vilnius First of all, attention should be drawn to the fact that at the beginning of 1944 the prewar boundary between the USSR and Poland was still valid, and this problem was one of the strategic obstacles that Stalin had to overcome. Soviet diplomacy had been speaking officially about the unacceptability of the Riga Line since the summer of 1941, when the Soviet ambassador to Great Britain Ivan Maisky and the prime minister of the Polish government-in-exile, Władysław Sikorski, signed a declaration on the re-establishment of diplomatic relations in London. ${ }^{10}$ Although in the declaration the Soviets recognized the annulment of their 1939 treaties with Germany concerning the Polish territories, they nevertheless treated the question of the future eastern Polish border actually open. As an alternative to the Riga Line, Soviet diplomats put forward the so-called ethnographic principle later identified as the Curzon Line. ${ }^{11}$ However, the Polish govern-

${ }^{9}$ N. Statkus, E. Motieka, Č. Laurinavičius, Geopolitiniai kodai (Vilnius, 2003).

10 Historia dyplomacji polskiej. Tom V. 1939-1945 (Warsaw, 1999), pp. 211-228.

11 The origin of term 'the Curzon Line' is related to the British Foreign Secretary Lord Curzon's note of 8 December 1919 to Lenin; in it the provisional eastern Polish border, established by the Supreme Council of the Allies on 8 December 1919, served the basis for the boundary between Poland and Soviet Russia. It was very near to the contemporary Polish eastern border. (See Dokumenty i materialy 
ment-in-exile, perceiving the link between the shifting of the borders to the west and the prospect of Poland's strength and self-sufficiency, refused to discuss this issue with the Soviets. This Polish stance was treated by the Soviets as an indication of unwillingness to maintain friendly contacts with the USSR. In the spring of 1943, when NKVD crimes including the Katyn massacre became obvious, the conflict between Moscow and the Polish government-in-exile reached a climax. Subsequently Moscow severed relations with the Polish government in London and began preparing for the formation of an alternative pro-Communist Polish government.

Meanwhile the Allies continued maintaining relations with the Polish government-in-exile. In confidential talks between Stalin, Churchill and Roosevelt at the Tehran Conference an agreement was reached in principle to draw the eastern border of Poland according to the Curzon Line; ${ }^{12}$ officially, however, the Allies took the position of not recognizing frontiers established by force. ${ }^{13}$ Therefore, US and British diplomats urged the Polish government-in-exile and the USSR to solve the problem of the frontiers by resuming a dialogue. Thus, at the start of 1944 the exact Polish-Soviet border was not yet clear not only to the Allies and to the Poles but also possibly to the Kremlin strategists.

At the beginning of 1944, the Red Army crossed the former Riga Line, and that provoked the renewal of the discussion between the USSR and the Polish government-in-exile. The development of the events in 1944 shows that a firm position of the Soviet leadership, despite its toughness in principle, contained some tendencies of flexibility, too. It depended on the situation at the fronts, on the position of the Allies and on the situation in the countries occupied by the Red Army.

An analysis of the statements in the exchange between the Soviets and the Polish émigré government in London at the beginning

po istorii sovetsko-polskikh otnoshenii, vol. 2 (Moscow, 1964), pp. 431-432; Dokumenty vneshnei politiki SSSR, vol. 3 (Moscow, 1959), pp. 47-52). In the initial stages of WWII rejecting the Riga Line for some time the Soviets emphasized the need of 'uniting Belarusian and Ukrainian territories' and 're-establishing the border of 22 June 1941 '. However, as these arguments implied associations with the Hitler-Stalin Pact of 1939, the Curzon Line was gradually acknowledged.

12 Sovetskii Soiuz na mezhdunarodnykh konferentsiiakh perioda Velikoi otechestvennoi voiny. Tegeranskaia konferentsiia rukovoditelei trekh soiuznykh derzhav - SSSR, SShA i Velikobritanii, (Moscow, 1984), p. 150.

13 L. Pastusiak, Roosevelt a sprawa polska, (Warsaw, 1980); Historia dyplomacji polskiej, pp. 457-467. 
of 1944 reveals the Kremlin attitude to discontinue a constructive dialogue with the government led by Stanisław Mikołajczyk. Stalin seemed unyielding, despite the letters of Churchill and Roosevelt in which they humbly asked him to continue that dialogue. At the same time he did not hide his intentions of forming an alternative Communist government for Poland. ${ }^{14}$ The situation became different when Churchill's tone changed and he made threats. On 19 March Stalin received Churchill's warning that due to the Soviet disregard of the legitimate Polish government the policy of the Allies in the cooperation with the USSR could be reviewed, specifically in the context of the 'Operation Overlord', i.e. opening a new front in the West. ${ }^{15}$ In his reply of 23 March Stalin rejected the threats appealing to the agreements of the Tehran Conference and asking rhetorically whether Churchill by chance was not going to disclaim the "liberation mission' of the USSR. ${ }^{16}$ The Polish sources, however, show that it was just at that time that the Polish government-in-exile received an offer from Soviet representatives (true, in a very confidential manner) to resume a dialogue. ${ }^{17}$ Thus, it seems that even in 1944 Stalin could not ignore the opinion of the Allies on the opening of a second front (as had been agreed in Tehran) and, most importantly, where it would be opened - in Western Europe or in the Balkans. ${ }^{18}$

According to Polish sources, negotiations between Poland and the USSR were conducted between March and July 1944 at three levels: with the Polish government-in-exile, with the partisans of the Armia Krajowa in the former eastern territories of Poland and with the Polish Communists in Moscow. A typical feature of these talks

${ }^{14}$ Dokumenty i materialy..., vol. 8 (Moscow, 1974), Doc. nos. 2, 4, 6, 7, 9, $12-15,17,22,23$.

${ }^{15}$ Ibid., Doc. no. 24.

${ }^{16}$ Ibid., Doc. no. 30. The myth of the 'liberation mission' of the Red Army was an ideological substantiation of the Soviet right to penetrate into Europe. The disavowal of this mission automatically meant a challenge not only to the Soviet Union but also to the whole anti-Hitler coalition.

${ }^{17}$ Historia diplomacji polskiej, pp. 496-505; S. Kirkor, 'Rozmowy polskosowieckie w 1944 roku', Zeszyty Historyczne, 1972, p. 22.

18 The agreement to open a second front in northern France meant the shortest way of defeating Germany. Meanwhile its opening in the Balkans would have entailed the participation of the Allies in the struggle for the influence in liberated Europe. Taking into account Churchill's endeavours to delay the opening of a second front in 1942 and 1943 and his support for the Balkan variant, it can be surmised that until the very landing of the Allies in Normandy on 6 June 1944 Stalin was not sure that the Tehran accords would be implemented. 
was delaying tactics. The dialogue between the Soviet envoy in London, Viktor Lebedev, and representatives of the Polish government-in-exile, and the discussions between the Soviet leaders and Polish Communist activists in Moscow started approximately at the same time. In both cases the Soviets tried to prolong the dialogue and to avoid bringing it to an end. The talks in London academically aired mutual past grievances and a future border between the two states. Lebedev, however, personally seems to have been interested only in a concrete question - the re-organization of the governmentin-exile, more precisely, the possibility of eliminating the members adamantly opposed to the rapprochement with the USSR (e.g. the chief leader K. Sosnowski) and linking the exile government with the Polish Communist activists. ${ }^{19}$ Such a variant was rejected by the London Poles. On 23 June Lebedev's tone changed suddenly and his position became uncompromising. On that day the Red Army launched its onslaught in Belarus towards Lithuania and Poland. Meanwhile in Moscow the formation of a new Communist government for Poland - the National Liberation Committee of Poland was in full swing. ${ }^{20}$

The talks between the Red Army and the units of the Armia Krajowa in the former eastern territories of Poland lasted from March until July. Under the cover of these contacts the Soviet side solved at least two problems. Firstly, there were discussions concerning operations against the Germans. This kind of cooperation took place in Wołyń, at Lvov and at Vilnius. Secondly, Moscow sought to ensure that the Allies adhered to the agreement which acknowledged the Red Army both strategic and operative exceptional freedom of action in a particular region. That meant that the Allies could not offer any assistance to the Armia Krajowa without Moscow's assent. ${ }^{21}$

${ }^{19}$ Dokumenty i materialy..., vol. 8 (Moscow, 1974), pp. 169, 174.

${ }^{20}$ Kirkor,'Rozmowy polsko-sowietskie', p. 22.

${ }^{21}$ In Polish historiography opinions vary about the attitude of the Allies towards Armia Krajowa. According to predominating statements in the spring of 1944, with the approach of the 'Operation Overlord', the British restricted greatly the contacts of the government-in-exile with the Armia Krajowa. (Historia dyplomacji polskiej, pp. 496-505; H. Mitkiewicz, 'Powstanie Warszawskie', pp. 95-156). Nevertheless, there is one more version stating that the British Air Force intensified supplies for the Armia Krajowa in order to provoke the ill-fated uprising (Jan Zamojski. 'Wielka Britania a Polska w świetle działalnośći Special Operations Executive', Dzieje Najnowsze, no. 1-2, 1971, pp. 314-328).

It is noteworthy that the Armia Krajowa was not treated by the Western Powers as an ally until the end of August 1944. 
Consequently, the Armia Krajowa units, used in the battles with the Germans and isolated from the rest of the world, could be eliminated easily by the Red Army without any major complications.

Thus, these episodes show that the Kremlin strategy closely linked the westward movement of the Red Army with the international political and geopolitical status quo. In this respect the Kremlin activities of 1944 would very much resemble those of the 1920 Warsaw campaign. ${ }^{22}$ If in the summer of 1920, when the Red Army was rapidly approaching Warsaw, the Kremlin had been prepared for far-reaching strategic changes depending on the alignment of forces, why cannot it be admitted that the Kremlin was prepared for similar twists and turns in 1944 as well? If at the start of August 1920, after London's breaking off negotiations with the Soviet emissary Leonid Krasin and after the outlawing of Bolshevism by Paris and Washington, the Kremlin actually changed its plans concerning the Communization of Poland (and Lithuania as well) despite the Red Army's continued advance towards Warsaw, so why could events not have developed similarly in 1944, if, for example, the Western Allies had curbed the Russophile propaganda in their countries?

Many Sovietologists are of the opinion that caution rather than direct confrontation was peculiar to Stalin's foreign policy. ${ }^{23}$ Really, it is worth deliberating - by relinquishing good relations with the Western Allies in 1944 what could Stalin expect but a prospect of being again isolated from the political processes in Europe and reconstructing the ruined economy of his country by its own resources. Finally, no matter how events could have developed, mere pondering on the implications of these alternatives creates conditions for not considering the actual development of 1944 events as 'ruthless determination'.

Dealing with the 1944 Soviet diplomacy it must be noted that one of the factors that Stalin used in tackling the Polish question and resisting Western pressure was sending signs about an eventual retreat from strict requirements of the Curzon Line. True, these signs were related mostly to the eventual Soviet retreat at the Lvov region

22 P.S. Wandycz, Soviet-Polish Relations. 1917-1921 (Cambridge, 1969); Č. Laurinavičius, Lietuvos-Sovietu Rusijos taikos sutartis (Vilnius, 1992).

${ }^{23}$ On Stalin's adherence to realpolitik, see Kissinger, Diplomacy, pp. 332510; M.P. Leffler, D.S. Painter (eds.), Origins of the Cold War. An International History (London, 1995), pp. 15-52; J.L. Gaddis, We Now Know. Rethinking Cold War History (Oxford, 1997). 
KALEIDOSCOPE OF POSSIBILITIES FACING LITHUANIAN STATEHOOD IN 194443

and offering vaguer hope for the Poles concerning Vilnius. ${ }^{24}$ For example, on a visit to Moscow in March 1944, the left-wing Polish professor Oskar Lange from the USA was accepted by Stalin, and during the reception he got the impression that Stalin considered the Lvov question open. ${ }^{25}$ The viewpoint of the President Roosevelt was similar, too. In June he assured Mikołaiczyk on his visit to Washington that 'territorial concessions on the part of Stalin are feasible' and that 'the President himself could help persuade Stalin concerning Lvov and possibly even Vilnius ... ${ }^{26}$ After a meeting with Stalin early in August Mikołaiczyk himself seems to have obtained the impression that 'the doors to Lvov were not shut' ${ }^{27}$ Retrospectively, there should not be any doubts that all of these 'impressions' were merely a consequence of the lures of the Kremlin sirens in their attempts to split the Polish government-in-exile. At the same time it is clear that in its strategic game the Kremlin used the territorial card as well. That, in its turn, attests to a possibility of the balance of forces in EastCentral Europe differing from that which actually emerged in 1944.

Some more manifestations of Moscow diplomacy could be referred to. On 21 July 1944, when a pro-Soviet manifesto of the Polish government was finally prepared in Moscow, the Deputy Prime Minister and Foreign Minister of the USSR Viacheslav Molotov proposed to make it public in Rovno, i.e. in a town located slightly to the west of from the Riga Line. ${ }^{28}$ Consequently, instead of the eventually known 'Chełm Committee' or 'Lublin Committee', 'the 'Rovno Committee' could enter into history with quite different associations than the really implemented one. If Lublin and Chełm

${ }^{24}$ Different attitudes towards the future of Vilnius and Lvov can also be detected in the stances of the Western diplomats. On 9 September 1943 the British Foreign Secretary Anthony Eden put an 'indiscreet' question to the Prime Minister of the Polish government-in-exile Stanisław Mikołaiczyk: 'Would the Poles agree to a modified Curzon Line according to which Lvov would remain Polish, the fate of Vilnius would be problematic, and Poland would receive Eastern Prussia and Silesia? (emphasis added). Historia, p. 420. On 16 February 1942 Churchill told Mikołaiczyk: 'We never guaranteed Poland's borders...we never endorsed the occupation of Vilnius in 1920..., Dokumenty i materialy, vol. 8, Doc. no. 23. Regrettably, the motives for this difference can only be inferred.

${ }^{25}$ Historia, p. 505.

${ }^{26}$ Dokumenty $i$ materialy, vol. 8, Doc. no. 51. It is noteworthy that Roosevelt raised the question of Lvov even in Yalta; Vilnius, however, was mentioned neither in Tehran nor in Yalta.

${ }^{27}$ Dokumenty i materialy, vol. 8, Doc. no. 92, p. 182.

${ }^{28}$ Ibid., Doc. no. 83, p. 170. 
symbolized the eastern bulwarks of the so-called ethnographic Poland, the inclusion of Rovno in Poland would have witnessed an evident retreat from the Curzon Line and a renewed intention to the partition of the historical lands of the Grand Duchy of Lithuania between Poland and Russia.

This circumstance is also important in that that it was a signal not so much to the London Poles as to their opposition, the proSoviet Polish camp. The Polish Communist leaders did not argue the Curzon Line basically, nevertheless, they could not afford to be indifferent to the Polish opinion on the new eastern border. Here is an instruction of a Polish Communist leader, Edward OsobkaMorawski, on the establishment of the border: 'It is essential to fix the border in such a way that the delegates of the Krajowa Rada Narodowa (the Lublin Committee was formed on its basis) would not be reproached with surrendering too many territories or that the Soviet Union would not be accused for incorporating too much' ${ }^{29}$

One more eventuality could be discussed: how the question of the eastern Polish border would have been solved if the Poles had succeeded to consolidate politically on the basis of anti-Nazism and created something like a National Liberation Front. In any case, such tendencies had been obvious since the spring of 1944 among the London émigrés as well. For example, on 30 March General Lucjan Żeligowski, well known in Lithuania, released a statement urging the Poles to unite among themselves and with other Slavs in the struggle against the 'aggressive Teutons' and at the same time to acknowledge the liberating mission of the Red Army. (Among other things, in his statement Żeligowski also recalled Vilnius, which he allegedly 'liberated from the Germans' in 1920). ${ }^{30}$ It is difficult to say how popular Żeligowski was in the government-in-emigration; his statement, nevertheless, evoked a response both in the Polish underground in Vilnius and in Moscow. It was published in the newspaper Izvestiia, and the Soviet diplomat Lebedev, in his meetings with the representatives of the Polish émigré government, showed particular interest in seeing the general personally in May and June 1944. ${ }^{31}$

${ }^{29}$ Ibid., Doc. no. 65, p. 136.

${ }^{30}$ Ibid., Doc. no. 38 , pp. $74-75$.

${ }^{31}$ Kirkor, 'Rozmowy', pp. 41-94. It should be noted that after his statement Żeligowski was called a 'great Polish patriot' by the Polish Communist organization in Vilnius 'Union of Polish Patriots'. Even at the Yalta Conference mention was made of Żeligowski; Stalin referred to him as one of those whom the Warsaw Poles (i.e. the pro-Communist government of Poland) would like to see in their ranks. 
Thus, it would be reasonable to put such a question: which country would Vilnius have come to, if at least before its occupation by the Red Army the Lublin Committee, organized by the Kremlin strategists, had comprised such members as the aforementioned general? Would the pro-satellite evolution of the Polish government have not been more acceptable to Stalin in the spring of 1944? In such a case the westward march of the Red Army would have gathered speed, there would have been less friction in the relations with the Allies, while the final solution of the border question could have been delayed.

The Red Army, however, took over Vilnius on 13 July, and the same day Stalin's statement about the liberation of the capital of Soviet Lithuania was issued. ${ }^{32}$ Rumours purportedly had circulated in the circles of the former Lithuanian nomenclature that it was only then that the leaders of the Lithuanian Communist Party in Moscow calmed down, since to the very last day they had not been quite sure to which Lithuanian city they would return to as the capital of the country...

Such apprehensions are attested indirectly by the archival materials of Lithuanian Communist activists. According to Romas Šarmaitis' diary, in February 1944 the Propaganda Department of the Central Committee of the CPSU requested a Russian translation of the Lithuanian national anthem (by Vincas Kudirka) and a popular inter-war song Mes be Vilniaus nenurimsim [We shall not rest without our struggle for Vilnius]. ${ }^{33}$ Such a request could mean that some influential Soviet figures, possibly including Stalin himself, might have been interested in the exact sense of texts meaningful to the Lithuanians. At the same time it could be a sign that the old anthem and the song could not be prohibited in Soviet-occupied Lithuania any more. The texts translated by Juozas Žiugžda were forwarded to corresponding institutions, and in actual fact Kudirka's anthem was not forbidden for some time in re-occupied Lithuania (in contrast to the years of the first Soviet occupation in 19401941). According to Šarmaitis, this permission meant 'depriving the national bourgeoisie of one more weapon'. ${ }^{34}$ Meanwhile who needed the song Mes be Vilniaus nenurimsim in the spring of 1944 and why?

32 'Prikaz tovarishcha Stalina', Pravda, 13 July 1944.

${ }^{33}$ LYA, f. 3377, ap. 57, b. 80, fo. 106.

${ }^{34}$ Ibid., fo. 108. 
To remind the Poles of Lithuanian moods or to let the Lithuanians understand that the time for complacency had not yet come? In any case, it is quite believable that the Red Army approaching Lithuania in the spring of 1944 the Kremlin had some alternate variants in addition to the model of the Soviet LSSR with the capital Vilnius.

\section{Was the LitBel variant in store as a Lithuanian-Polish Interna-} tional? The material presented above shows how the Soviet leadership taking into account a hostile, or more precisely, an unmanageable Polish factor played the territorial trump card. And, as has been indicated above, a possibility, slight as it might be, could be assumed as a variant in the Soviet political armoury according to which the Vilnius Region could be part of a re-establishing state of Poland. However, one can also propose a version that the variant 'Vilnius stays in Poland' seems to have been more credible than the variant according to which, taking into account the Polish factor and trying to neutralize it, attempts could be made to reconstruct the Lithuanian state on non-ethnic grounds, i.e., to form a structure, similar to the LitBel of 1919 in which Lithuanian and Polish Communists were offered key posts, as in the case of the government of Kapsukas and Cichowski in February 1919. This kind of reasoning is supported by the circumstance that neither accessible archival materials nor related writings present any clearer traces of plans to transform the Lithuanian-Soviet government by involving Polish representatives in it.

The records of Antanas Sniečkus, made between 1941 and 1944 in Moscow, are worth a closer study. They hardly contain any hints concerning the need for Lithuanian-Polish consolidation even in the context of the pro-Soviet orientation. On the contrary, comments, accentuating the national and social differences, peculiar to the Lithuanians and the Poles, are quite frequent. A note, made on 2 August 1943, runs as follows: 'In Lithuania the Polish nationalists are endeavouring to engage the Lithuanian nationalists in a struggle for an independent Polish-Lithuanian state under the aegis of Great Britain. It is necessary to make clear the plans of Polish reaction...' ${ }^{35} \mathrm{~A}$ somewhat later record says: 'Polish counter-revolutionary organizations are preparing for an uprising...they are bitter enemies of the USSR... ${ }^{36}$ After a visit to General Krylov's headquarters

${ }^{35}$ LYA, f. 16895 , ap. 2, b. 194 , fo. 34.

${ }^{36}$ Ibid., fo. 54. 
on 11 July Sniečkus wrote: 'It is vital to disarm and exile the men of the Armia Krajowa...'37

These notes of Sniečkus are scrappy and barely legible. Nevertheless, they, too, show that the attitudes towards Poles and Lithuanians were different. For example, noteworthy is a record concerning the so-called Plechavičius' men: It is necessary to foster the conflict between Plechavičius' men and the Germans...to prevent the disarmament of Plechavičius' men...to carry a common struggle with them against the Germans...in the course of the struggle to eliminate the implacable enemies of Soviet power'. ${ }^{38}$ A record of 25 June 1944 informs that 'Local [Lithuanian] nationalists proposed that their leaders met Soviet partisans...the meeting is possible if it is related to the formation of common headquarters at which Soviet partisans would be represented and their own headquarters would not be eliminated...' 39

The situation is further clarified by two complaints, sent by the head of the Administrative Department of the Central Committee of the LCP, Daniil Shupikov, to the Secretary of the Central Committee of the CPSU, Georgii Malenkov, on 15 July and 6 September 1944. ${ }^{40}$ These complaints show that there were plans to exile all (my emphasis) the inhabitants of liberated Lithuania as 'counter-revolutionary elements' endangering the rear of the Red Army. The case would have been similar to the deportation of the Crimean Tartars and other nations. However, according to Shupikov, these plans were opposed by the leaders of the LSSR, and consequently only the Poles were re-settled. In Shupikov's words, the leaders of the LCP Preikšas, Paleckis and Sniečkus not only preferred the Lithuanians to the Poles, they also conducted an evident policy of reconciliation with Lithuanian bourgeois activists.

In general, both Shupikov's complaints and other documents imply that the LCP leaders were inclined to develop a certain, possibly only cosmetic, political support in liberated Lithuania. At the same time it must be noted that this orientation was related only to the Lithuanian nation. It would be possibly too bold to treat this phenomenon as an attempt to create a structure resembling a National Front. On the other hand, it is hardly believable that this policy of the LCP leadership, according to Shupikov clearly coun-

${ }^{37}$ V. Tininis, Sniečkus (Vilnius, 2000), p. 64.

${ }^{38}$ Ibid., p. 60.

${ }^{39}$ Ibid. 
ter-revolutionary, was pursued without support, possibly even from Stalin himself.

It is likely that Stalin needed the Lithuanians in the territorial contest with Poland. As the Polish government-in-exile, defending the Riga Line, drew on the so-called principle of 'the polyethnic republic', it is little wonder that ethnographic arguments were used as an antithesis. ${ }^{41}$ It can also be surmised that the need for the Lithuanians and respectively the search for the consolidation of the political forces in Lithuania depended on the extent of the complication of the rivalry with Poland. Meanwhile the principle of class purity could be either postponed or at least blocked. Thus, it can be assumed that in case of the failure of the variant 'the LSSR with Vilnius' something like 'the People's Democratic Republic of Lithuania' could be deliberated. Consequently, one could think about Lithuania with its tricolour, the national anthem created by Vincas Kudirka and a government comprising such public figures as Domas Cesevičius, Kazimieras Ambrozaitis and even Aleksandras Stulginskis, Juozas Tonkūnas, all of them released from the gulags, ${ }^{42}$... and maybe even Krèvè ... ${ }^{43}$ And the song Mes be Vilniaus nenurimsim would still be sung in such a Lithuania.

\section{Concerning the Possibilities of Territorial Compensations}

However, social and national symbols alone could hardly compensate the loss of Vilnius in Lithuanian consciousness. Therefore the question of compensation was unavoidable. Judging from the projects submitted to the British Foreign Secretary Anthony Eden by the Soviet leadership in Moscow as far back as December 1941 it seems

${ }^{40}$ LYA, f. 3377 , ap. 58 , b. 854 , fos. $1-4$.

${ }^{41}$ Cf. the argumentation in the Polish-Soviet negotiations in July 1941 (Historia dyplomacji polskiej, pp. 216, 218); the 3 May 1943 speech of the Polish President Władysław Racewicz (Tarka, Konfrontacja, pp. 144-145).

42 Šarmaitis' diary contains the following note, dated 23 June 1944: 'More deportees are coming back. Many of them are released ... the international situation of the USSR has changed. Hostile elements are no more dangerous ... Soviet Lithuania was accepted by Cesevičius, Ambrozaitis, and others. The Germans say that that was done under pressure ... Stulginskis, Tonkūnas and Stanišauskis also said that already in 1942, however, none of them spoke manifestly in favour of Soviet Lithuania ... Valsiūnienė, Dovydaitis, Grèbliauskienė and Mikšienè are among the released. (LYA, f. 17635, ap. 1, b. 15, fo. 116).

${ }^{43}$ Informing on the Lithuanian leadership, Shupikov wrote to Malenkov that 'they do not want to arrest intellectuals' and allegedly Krève was 'walking free' in Vilnius (LYA, f. 3377, ap. 58, b. 854, fo. 4). 
that the Königsberg Region was to be joined to Lithuania if Vilnius remained part of Poland. ${ }^{44}$ Therefore it was probably not accidental that at the beginning of 1944 Molotov enquired of the leaders of the LCP what they would like to annex to Lithuania from East Prussia (in addition to the Klaipeda Region, concerning the belonging of which to Lithuania apparently there were no doubts). ${ }^{45}$ That is attested by the memoirs of Romas Šarmaitis and Juozas Vaišnoras. ${ }^{46}$ They show that a commission, consisting of Juozas Pakarklis, Juozas Žiugžda, Boris Larin and Juozas Vaišnoras, reached the following conclusions: to annex Tilsit, Insterburg, Gumbinnen and Tolminkehmen to Lithuania, and to consider the incorporation of Königsberg inexpedient, since Lithuania did not have the population sufficient for the resettlement of the city. The commission also noted that Lithuania's primary objective was the settlement of Vilnius.

The commission's proposals were submitted to the Soviet government whose reaction to this issue remained unknown. Subsequently no area of East Prussia was added to the Klaipeda Region. It is not known when the commission presented its conclusions before or after 13 July 1944. In any case one cannot reject a presumption that the commissioners may have been worried about the idea that the annexation of Königsberg to Lithuania would raise doubts about the expedience of attributing Vilnius to the country.

\section{Concerning the Eventuality of (pro)Soviet Lithuania as an anti-} Polish Buffer Of all the major events of 1944 the Warsaw Uprising was of crucial importance for determining the situation of Lithuania and the entire region. If the Insurgents, led by the exiled Polish government in London, had succeeded in driving the Germans out of the city in the first days of September and had met the Red Army with an actually functioning government of sovereign Poland, the Soviet Union would possibly have been confronted with

44 'Dopolnitel'nyi protokol k sovetsko-angliiskomu dogovoru'. Rossiiskii gosudarstvennyi arkhiv sotsial'no-politicheskoi istorii (RGASPI), Moscow, f. 558, op. 1, d. 279 , fos. $144-147$.

${ }^{45}$ It is noteworthy that at the Tehran Conference Stalin mentioned Königsberg and Memel in his reference to Russia's need for ice-free ports in the Baltic Sea. (Sovetskii Soiuz na mezhdunarodnykh konferentsiiakh perioda Velikoi otechestvennoi voiny. Tegeranskaia konferentsiia rukovoditelei trekh soiuznykh derzhav - SSSR, SShA i Velikobritanii, vol. 2 (Moscow, 1984), p. 150). Later, in Potsdam, a separate chapter was devoted to Königsberg, while no mention was made of Memel.

${ }^{46}$ LYA, f. 17635 , ap. 1 , b. 15 , fo. 107 ; f. 3377 , ap. 51 , b. 251 , fos. $61-63$. 
a serious obstacle in extending its influence over Lithuania and the neighbouring Baltic countries. However, the Germans did not retreat easily from Poland, while the Red Army ceased its advance on Warsaw and the Uprising was doomed to failure.

Nevertheless, the course of the Uprising is worth closer analysis. Initially the Soviet Union viewed this Polish action unfavourably and not only offered it any support but actually forbade the Allies to do that. ${ }^{47}$ This situation continued for nearly a month. However, at the very end of August the attitude of the USSR began to change. The propaganda condemning the rising ceased. The chief commanders of the Red Army, Georgii Zhukov and Konstantin Rokossovskii, were sent to the Warsaw Front, and the initial more or less real efforts to support the uprising became evident in the first week of September. ${ }^{48}$

The reasons for this change of Soviet policy may have been manifold. It could have been caused by the indignation of the Allies, and the assumption that it was a way of prolonging the agony of the Uprising could be reasonable, too. However, noteworthy are the measures taken by the Poles of London and the Insurgents of Warsaw. On 28 August the Polish government-in-exile issued a declaration officially expressing its consent to the formation of a joint government. ${ }^{49}$ The following day the USA and Great Britain recognized the rebels as an Allied Army thus increasing pressure on the Soviets. Afterwards the leader of the Warsaw Uprising Tadeusz BórKomorowski wrote a letter to General Rokossovski which contained both a request for help and an acknowledgement of the liberating mission of the Red Army. ${ }^{50}$ Thus the Polish government-in-exile (or at least some of its members) and the political leadership of the Warsaw Uprising accepted a major principle of the Soviet Union, and the Soviet leadership could no longer ignore that circumstance taking into account the fact that there were Polish troops in the Red Army standing at Warsaw.

If the Soviets took measures to support the Uprising, it is believable that they must have been prepared for the eventuality of

${ }^{47}$ Dzh. Kennan, Diplomatiia vtoroi mirovoi voiny (Moscow, 2002), pp. 128139. This publication is based on G. F. Kennan, Memoirs, 1925-1950 (BostonToronto, 1967).

${ }^{48}$ R. Nazarevich, 'Varshavskoe vosstanie. 1944', Novaia i noveishaia istoriia, no. 2, 1989, pp. 186-210.

49 Dokumenty i materialy po istorii sovetsko-polskikh otnoshenii. Vol. 8, document no. 116, pp. 206-208.

${ }^{50}$ Nazarevich, 'Varshavskoe vosstanie', pp. 199-206. 
its victory and the appearance of at least a relatively independent government in Poland. In this context the following fact does not seem sheer coincidence: at the very end of August the USSR proposed to include all the sixteen Soviet republics in the UNO at the Dumbarton Oaks Conference in 1944. Since Roosevelt firmly rejected this proposal, the Soviet side agreed to the admission of three Soviet republics - Ukraine, Belarus and Lithuania. ${ }^{51}$

This attempt to introduce Lithuania as a subject in the activity of international organizations was not a new phenomenon in Soviet diplomacy. For example, in 1943 efforts were made to introduce the Soviet republic of Lithuania (and Latvia and Estonia, too) in the United Nations War Crimes Commission. ${ }^{52}$ At that time the British and the Americans resisted the proposal taking it as an endeavour of the Soviet Union to achieve a de facto recognition of its borders of 22 June 1941. This objective could have existed at the Dumbarton Oaks Conference, too. In the latter case, however, the situation was more complicated - Ukraine, Belarus and Lithuania were republics whose territories had been enlarged at the expense of Poland. A successful aftermath of the Polish Uprising would have led to at least the relative independence of the country from Moscow, and consequently, Poland would have hardly reconciled to the Curzon Line. Thus, the Soviet republics of Ukraine, Belarus and Lithuania would have played a buffer role in the territorial quarrel with Poland, as had been the case with the LitBel. The question concerning the rank of Lithuania as a state subject in that role can be only an academic one.

The discussions about the participation of the above-mentioned Soviet republics in the UNO continued until the Yalta Conference. It was then agreed to grant membership to Ukraine and Belarus, while the Lithuanian question was not mentioned by tacit gentlemen's agreement. ${ }^{53}$ At the same time, the agreements reached at Yalta opened the doors wide for Poland's Communization, and the eventual buffer role of the neighbouring Soviet republics lost all relevance.

Conclusion The blueprint of Kremlin strategy in the Second World War presented in this article would lead to the idea that the

51 Sovetskii Soiuz..., Konferentsiia v Dumbarton-Okse (Moscow, 1984), p. 15.

52 Ariech J. Kochavi, 'Britain, the Soviet Union, and the Question of the Baltic States in 1943', Journal of Baltic Studies, 22/2, (1991), pp. 173-182.

53 E.R. Stattinius, The Diaries (New York, 1975), p. 175. 
westward march of the Red Army in 1944, historically neither inevitable from the modern point of view nor inexorable in the then situation, was not the only factor which conditioned the future of Lithuania and the entire region. The course of history could have been different if a variety of other factors had proved to be deciding.

Firstly, an eventual Lithuanian-Polish political agreement should be mentioned. Though there was very little likelihood of that happening during the Second World War, nevertheless, a potential significance and possible effect cannot be disregarded totally.

Secondly, in 1944 Lithuania's eventual status depended greatly on the future status of Poland. In this respect Stalin's strategy practically did not differ from that of Lenin in 1918-1920. Lithuania was seen by the Kremlin as a space potentially influenced by Poland, and the probability of Lithuania's dependency on Russia was inversely proportional to the degree of the sovereignty of reconstructed Poland.

If, for example, Polish politicians had succeeded in establishing a National Liberation Committee, analogous to the French one, in the struggle against the Nazis by the summer of 1944, then, according to such a version, Stalin would have run into difficulties with the intrusion of the concept of the Curzon Line upon Poland. The Kremlin had undoubtedly forestalled such an eventuality and had prepared a variant according to which Lithuania had to play a nationalistically anti-Polish pro-Soviet-satellite role, similar to the inter-war one. Incidentally, it seems that the already legendary proposal to attach Königsberg to Lithuania can be discussed only in this context. ${ }^{54}$ This variant could be planned as compensation to Lithuania for Vilnius and as a preventive measure of the transfer of Königsberg to Poland. (it is common knowledge that already at the end of 1939 the émigré government of Gen. Władisław Sikorski started laying claim to East Prussia and Königsberg as part of postwar Poland, and it was only in 1943 that Stalin openly used his initiative in taking over East Prussia). ${ }^{55}$

If the nationalist forces of Poland had succeeded in meeting the Red Army in a Warsaw under their own control, the role of Lithua-

${ }^{54}$ Concerning a version of offering Königsberg to Lithuania, see A. Kulakauskas, 'Komentaras', Lietuva ir jos kaimynai. VU Tarptautiniu santykiu ir politikos mokslu instituto metinès konferencijos 1996 m. lapkričio 22-23 d. tekstai (Vilnius, 1997), pp. 136-138.

${ }^{55}$ Historia dyplomacji polskiej, vol. 5, p. 140. 
nia would have been similar to that of the LitBel buffer-bridgehead both in the negotiations with Warsaw on the borders and in eventually furthering the impending Sovietization of Poland.

In this context certain differences can be noticed in the strategies of Lenin and Stalin. The 1919 Litbel model shows an imitation of historical civil society, while Stalin's strategy is based on the concept of the so-called modern ethnographic principle. In drawing a dividing line between Lithuania and Poland, Stalin was more resolute not only than Lenin but also than the former governments of tsarist Russia, which in their time were undecided as to how to draw a line between the re-established Kingdom of Poland and the Russian Empire. ${ }^{56}$ True, Stalin's delimitation of the frontier between Lithuania and Poland was carried out in the aftermath of the faits accomplis.

Lastly, the third factor was the position of the Western Allies. In dealing with Stalin, Roosevelt and Churchill were guided by the principle of the main strategic interest - to exploit the might of the Red Army in order to crush the power of Nazi Germany. It is also doubtless that the Allies, actually giving Stalin a free hand in the Eastern Baltic, also took into account the hopeless Lithuanian-Polish conflict, the difficulties of national consolidation in Poland and other related problems in the region. In this situation the Allies adhered to the so-called strategy of the indefiniteness of war aims, which meant avoiding concrete commitments and the postponement of the solution of a number of issues until the end of the war.

The Allies had one more strategic model: to conclude definite agreements concerning the post-war order with the war still going on and in this way to limit the influence of the Soviet Union, specifically in the Eastern Baltic region. For example, in Henry Kissinger's opinion, in 1942 it was still possible to exact the re-establishment of the Baltic states as they were in 1940, i.e. with Soviet military bases on their territories. ${ }^{57}$ This principle was clearly favoured by the British, and it is believable that Stalin would have accepted it if the Americans had supported the British. However, such prearranged agreements were unacceptable to the Americans. The historic irony is that the chance to re-establish the Baltic states as they were in

${ }^{56}$ Concerning the policy of pre-Bolshevik Russia on the issue of drawing a line between Lithuania and Poland, see R. Lopata, 'Lietuvos valstybingumo raida', Lietuviu atgimimo istorijos studijos, vol. 9, (Vilnius, 1996), pp. 11-55.

${ }^{57}$ Kissinger, Diplomacy, p. 403. 
1940 somehow seemed to the Americans 'too minimalist' and 'too maximalist' at the same time: 'minimalist' because the Soviet bases remained there and 'maximalist' because consequently the Baltic nations were to be subjugated for fifty years, while the Americans had to conduct the cold war with the Soviets all those fifty years for the sake of the Baltic states as well. ${ }^{58}$

The decision of the Allies to support the re-establishment of the Baltic states according to their status in 1940 with the battles still fought on the Eastern front would have meant their preconceived decision concerning the westward shifting of the Polish eastern border. Such a commitment would have been hardly acceptable to Western democracies. However, a number of indirect sources attest to a tacit approbation of the model 'Lithuania with Vilnius and Klaipèda' by Washington and London.

All in all, the discussed episodes of 1944 lead to the conclusion that in the Second World War Lithuania was a rather important object (and admittedly a prospective potential subject) of world politics. The fact that after the war Lithuania did not become an international subject would not justify the depreciation of such possibilities. The depreciation and resignation to 'ruthless determination' would actually lead to the submission of the Lithuanian political thought.

Translation: Alfonsas Laučka

\section{Author Details}

Dr Česlovas Laurinavičius is head of the Department of 20th Century History, Lithuanian Institute of History. He is the author of four monographs and numerous articles on political history and geopolitics.

Address: Department of 20th-Century History, Lithuanian Institute of History,

Kražių 5, LT-01108 Vilnius, Lithuania

E-mail: laurinav@yahoo.com

${ }^{58}$ According to some sources, at the end of 1942 in his meeting with Stalin Roosevelt still intended to raise the issue of the re-establishment of the Baltic states by according to Soviet with the protectorate right. Cf. P. Grudziński, Przyszłość Europy w koncepcjach Franklina D. Roosevelta (1933-1945) (Wrocław, 1980), p. 127. 


\section{LIETUVOS VALSTYBINGUMO GALIMYBIỤ MOZAIKA: 1944 METAI}

Santrauka

\section{ČESLOVAS LAURINAVIČIUS}

Straipsnyje svarstoma padètis, susiklosčiusi Lietuvoje 1944 metais, tai yra alternatyvos sovietinès Lietuvos su Vilniumi bei Klaipeda variantui. Apsvarstytos tokios galimybès: Lietuvos be Vilniaus, Lietuvos su vadinamaja liaudies demokratijos politine sistema, Lietuvos su teritoriniu išsiplètimu Karaliaučiaus srityje ir Lietuvos kaip buferio prieš eventualiai savarankišką Lenkiją.

Galimybès apsvarstytos analizuojant Kremliaus politiką lenkiškojo faktoriaus atžvilgiu bei SSRS santykius su Vakarų sajungininkais $1944 \mathrm{~m}$. Taip pat remtasi to meto lietuvių komunistų refleksija. $1944 \mathrm{~m}$. situacijos alternatyvų modeliavimui analogijų ieškota Raudonosios armijos žygyje ị Vakarus 1918-1920 m.

Nepaisant apsvarstytų variantų hipotetiškumo bei neapibrèžtumo, daroma išvada, kad Kremlius 1944 m. Lietuvos atžvilgiu veike atsižvelgdamas ne tik į Raudonosios armijos potencialą, bet ir į lenkiškojo veiksnio raidą bei i Vakarų sajungininkų poziciją. Daroma išvada, kad Lietuvos suverenumo bei teritorinio apibrèžtumo situacija neišvengiamai būtų kitusi didejjant Lenkijos suverenumo laipsniui ir netgi griežtejjant T. Ruzvelto bei V. Čerčilio tonui Stalino atžvilgiu. 
